\title{
Mechanical Property Evaluation of Si-SiC Matrix C/C Composite with the Use of Complex Rules
}

\author{
Shigeru Hanzawa \\ NGK Insulators, Ltd. \\ 2-56 Suda-cho, Mizuho, Nagoya, Aich 4678538, Japan \\ Tel: 81-52-872-7746 E-mail: hanzawa@ngk.co.jp \\ \& \\ Ceramics Research Laboratory, Nagoya Institute of Technology \\ 10-6-29 Asahigaoka, Tajimi, Gifu 5070071, Japan \\ Tel: 81-57-227-6811
}

Received: February 23, 2012

Accepted: March 11, 2012 Published: April 1, 2012

doi:10.5539/jmsr.v1n2p221

URL: http://dx.doi.org/10.5539/jmsr.v1n2p221

\begin{abstract}
$\mathrm{Si}-\mathrm{SiC}$ matrix $\mathrm{C} / \mathrm{C}$ composites are known to be synthesized through the following process. With the $\mathrm{C} / \mathrm{C}$ composite having a yarn-like structure of carbon fibers as a base material, the $\mathrm{Si}-\mathrm{SiC}$ matrix $\mathrm{C} / \mathrm{C}$ composite is obtained by synthesizing a trunk $\mathrm{Si}-\mathrm{SiC}$ matrix after impregnating $\mathrm{Si}$ into the clearances between yarns and then synthesizing a branch $\mathrm{Si}-\mathrm{SiC}$ matrix which stretches from the trunk $\mathrm{Si}-\mathrm{SiC}$ to the inside of the $\mathrm{C} / \mathrm{C}$ composite. Compressive strength of the $\mathrm{Si}-\mathrm{SiC}$ matrix $\mathrm{C} / \mathrm{C}$ composite is increased up to about twice as large as that of the base material $\mathrm{C} / \mathrm{C}$ composite. However, the tensile strength of this composite is decreased to about one fourth of that of the base material $\mathrm{C} / \mathrm{C}$ composite, and the bending strength is decreased to about a half of that of the base material $\mathrm{C} / \mathrm{C}$ composite. This paper reports that 1 ) degradation of tensile/bending strength caused on the $\mathrm{Si}-\mathrm{SiC}$ matrix $\mathrm{C} / \mathrm{C}$ composite is an unavoidable phenomenon and 2) a technique for forming only a part of the base material $\mathrm{C} / \mathrm{C}$ composite into the $\mathrm{Si}-\mathrm{SiC}$ matrix structure is an effective means of structural component design by increasing compressive strength of the base material $\mathrm{C} / \mathrm{C}$ composite and restraining degradation of tensile/bending strength.
\end{abstract}

Keywords: $\mathrm{C} / \mathrm{C}$ composite, $\mathrm{Si}-\mathrm{SiC}$ matrix, $\mathrm{Cu}$ matrix, Degradation of strength, Complex rules

\section{Introduction}

Si impregnated C/C composites (Evans, et al., 1976) were developed in the 1970s as a material having features such as heat resistance, abrasion resistance, oxidation resistance intrinsic to $\mathrm{Si}$ impregnated $\mathrm{SiC}$ ceramics (Popper, 1961) and having light weight and high strength intrinsic to carbon fiber reinforced carbon (hereinafter referred to as $\mathrm{C} / \mathrm{C}$ ) composite (Wrzesien, et al., 1976). However, there are still few cases where this $\mathrm{Si}$ impregnated $\mathrm{C} / \mathrm{C}$ composite has been utilized for industrial components.

This is because the Si impregnated C/C composite (Fitzer, 1987) produced by synthesizing Si-SiC matrix in pore parts on the carbon fibers while maintaining carbon fiber structure and characteristics (suggested by Fitzer) do not have the strength for them to be used as structures which need to be impervious to the stress from actual temperatures and forces in real applications. So far, authors have figured out its synthesizing mechanism by synthesizing a three-dimensional structural matrix of $\mathrm{Si}-\mathrm{SiC}$ using the $\mathrm{C} / \mathrm{C}$ composite (Chang, Nakagawa \& Okura, 1991) having a structure of carbon fiber yarns and using its characteristic pore structure and then by creating the $\mathrm{Si}-\mathrm{SiC}$ matrix C/C composite (Hanzawa \& Nakagawa, 2002; Hanzawa \& Nakagawa, 2003; Hanzawa, 2005) while converting only a part (12 Vol.\%) of the carbon fiber to $\mathrm{SiC}$ and leaving the most part of the carbon constituent (Hanzawa, 2012).

This paper clarifies the drawbacks and advantages of the mechanical properties of the $\mathrm{Si}-\mathrm{SiC}$ matrix $\mathrm{C} / \mathrm{C}$ composite in comparison with the mechanical properties of the $\mathrm{C} / \mathrm{C}$ composite (base material thereof) and the $\mathrm{Cu}$ matrix $\mathrm{C} / \mathrm{C}$ composite. Furthermore, factors that vary the mechanical properties of the base material $\mathrm{C} / \mathrm{C}$ composite by the $\mathrm{Si}-\mathrm{SiC}$ matrix synthesis are analyzed using comparative observation with a structure of $\mathrm{Cu}$ 
matrix and complex rules. In addition, this paper verifies that partial $\mathrm{Si}-\mathrm{SiC}$ matrix $\mathrm{C} / \mathrm{C}$ composite, devised to compensate for the drawback that properties deteriorate when the $\mathrm{Si}-\mathrm{SiC}$ matrix and the $\mathrm{C} / \mathrm{C}$ composites are combined, is an effective means for structural component design.

\section{Experimental Procedure}

Three kinds of materials are used for this experiment: 1) AC200 (AC200 made by ACROSS Co, http//:www.across-cc.co.jp/jp/about_c_c/technology.html) C/C composite (Chang, Nakagawa \& Okura, 1991) having a structure in which a sheet of carbon fiber yarn extending in the direction of $0^{\circ}$ and a sheet of carbon fiber yarn extending in the direction of $90^{\circ}$ are laminated alternately, 2) $\mathrm{Si}-\mathrm{SiC}$ matrix $\mathrm{C} / \mathrm{C}$ composite (Hanzawa, 2012) in which $\mathrm{Si}$ is impregnated in the $\mathrm{C} / \mathrm{C}$ composite (AC200) before being synthesized, 3) $\mathrm{Cu}$ matrix $\mathrm{C} / \mathrm{C}$ composite (Hanzawa \& Ishikawa, 2003) in which $\mathrm{Cu}$ is impregnated in the $\mathrm{C} / \mathrm{C}$ composite (AC200) before being synthesized.

$\mathrm{Si}-\mathrm{SiC}$ matrix $\mathrm{C} / \mathrm{C}$ composite is prepared according to a method (Hanzawa, 2012) for heating raw materials, which are prepared by taking Si powder in the $\mathrm{C} / \mathrm{C}$ composite $(\mathrm{AC} 200 / 100 \times 100 \times 10 \mathrm{~mm})$, at $1600^{\circ} \mathrm{C}$ in an atmosphere of argon with $100 \mathrm{~Pa}$ of pressure and impregnating $\mathrm{Si}$ into the $\mathrm{C} / \mathrm{C}$ composite. Figure 1 shows $\mathrm{X}$-ray diffraction data of the composite, and a part of carbon constituent comprising the $\mathrm{C} / \mathrm{C}$ composite reacts with impregnated $\mathrm{Si}$ to be converted to $\mathrm{SiC}$. On the other hand, $\mathrm{Cu}$ matrix $\mathrm{C} / \mathrm{C}$ composite is prepared as follows: a crucible with $\mathrm{C} / \mathrm{C}$ composite $(\mathrm{AC} 200 / 100 \times 100 \times 10 \mathrm{~mm}$ ) and a mass of $\mathrm{Cu}$ is put in a furnace first of all, these are heated at $1150^{\circ} \mathrm{C}$ in vacuum, the $\mathrm{C} / \mathrm{C}$ composite in a state of heating/vacuum is immersed in a crucible in which molten copper is contained, and then $\mathrm{Cu}$ is impregnated in the $\mathrm{C} / \mathrm{C}$ composite by maintaining the temperature and filling nitrogen to increase furnace pressure up to $100 \mathrm{kgf} / \mathrm{cm}^{2}$. Continuously, a method (Hanzawa \& Ishikawa, 2003) for pulling up the $\mathrm{Cu}$ impregnated $\mathrm{C} / \mathrm{C}$ composite from the crucible in an atmosphere of nitrogen at high temperature/pressure and then rapidly quenching immediately was used. Figure 2 shows X-ray diffraction data of the composite thus obtained: there is no reaction between carbon constituent and $\mathrm{Cu}$ constituting the $\mathrm{C} / \mathrm{C}$ composite; the $\mathrm{C} / \mathrm{C}$ composite is comprised only of carbon and $\mathrm{Cu}$.

Thus obtained group of materials and base material $\mathrm{C} / \mathrm{C}$ composite are processed into a specimen to evaluate the properties. Directions of processing property evaluation specimen are as shown in Figure 3: in view of the orientation of carbon fiber yarn in the $\mathrm{C} / \mathrm{C}$ composite, the direction of the carbon fiber yarn aligned in the direction of $0^{\circ}$ is determined to be the direction $\mathrm{X}$, the direction of the carbon fiber yarn aligned in the direction of $90^{\circ}$ is determined to be the direction $\mathrm{Y}$, and the direction of sheet lamination of the carbon fiber yarn is determined to be the direction $\mathrm{Z}$.

\section{Experimental Results (Mechanical Properties)}

Bulk density/porosity and bending strength, bending elastic modulus, compressive strength at room temperature of the $\mathrm{Si}-\mathrm{SiC}$ matrix $\mathrm{C} / \mathrm{C}$ composite, the $\mathrm{Cu}$ matrix $\mathrm{C} / \mathrm{C}$ composite, and the $\mathrm{C} / \mathrm{C}$ composite $(\mathrm{AC} 200)$ used for the base material of these composite were measured.

Measurement of bulk density/porosity was made according to Archimedes method (at normal temperature) using specimens processed to a length of $X=4 \mathrm{~mm}, Y=40 \mathrm{~mm}, Z=3 \mathrm{~mm}$ for all three kinds of composite. Measurement of bending strength and bending elastic modulus is made using specimens processed to a length of $X=4 \mathrm{~mm}$, $\mathrm{Y}=40 \mathrm{~mm}, \mathrm{Z}=3 \mathrm{~mm}$ for all three kinds of composite and using 4-point bending method by applying load from the direction $Z$ (lower span of $30 \mathrm{~mm}$, upper span of $10 \mathrm{~mm}$, crosshead speed of $0.5 \mathrm{~mm} / \mathrm{min}$ ). Value of bending strength is calculated in conformity to JIS-R1663 (2004). Value of bending elastic modulus is calculated in conformity to JIS-R1644 (2002). Furthermore, measurement of compressive strength is made using specimens processed to a length of $X=10 \mathrm{~mm}, Y=10 \mathrm{~mm}, Z=10 \mathrm{~mm}$ for all three kinds of composite, by applying load from the direction $\mathrm{Z}$ crosshead speed $0.5 \mathrm{~mm} / \mathrm{min}$, (Using the universal testing equipment, AG-25TA, SHIMADZU Co.), in conformity with JIS-R1673 (2007) so as to measure strength that a specimen buckles. Table 1 shows Mechanical properties of $\mathrm{C} / \mathrm{C}$ composite, $\mathrm{Si}-\mathrm{SiC}$ matrix $\mathrm{C} / \mathrm{C}$ composite and $\mathrm{Cu}$ matrix $\mathrm{C} / \mathrm{C}$ composite. In the table, tensile strength data and tensile elastic modulus data are taken from report of Wang et al. (2008).

From characteristic values in Table 1, with regards to the $\mathrm{Cu}$ matrix $\mathrm{C} / \mathrm{C}$ composite densified without associated with new reaction synthesis between the impregnated $\mathrm{Cu}$ and the base material $\mathrm{C} / \mathrm{C}$ composite, each value of compressive/bending/tensile strength and elastic modulus is increased more than those of the base material $\mathrm{C} / \mathrm{C}$ composite, and therefore it can be said that $\mathrm{Cu}$ impregnation into the $\mathrm{C} / \mathrm{C}$ composite contributes to improvement of these mechanical properties.

We found that synthesizing the $\mathrm{Si}-\mathrm{SiC}$ matrix in the $\mathrm{C} / \mathrm{C}$ composite may not contribute to improvement of the mechanical properties of the $\mathrm{C} / \mathrm{C}$ composite. This is due to the $\mathrm{Si}-\mathrm{SiC}$ matrix $\mathrm{C} / \mathrm{C}$ composite being densified 
incident to $\mathrm{SiC}$ synthesizing reaction between the impregnated $\mathrm{Si}$ and the base material $\mathrm{C} / \mathrm{C}$ composite. There is a positive factor of increased compressive strength $(+105 \%$ to base material $\mathrm{C} / \mathrm{C}$ composite $)$ and increased bending elastic modulus $(+27 \%$ to base material $\mathrm{C} / \mathrm{C}$ composite). However, there is a negative factor of decreased bending strength $(-54 \%$ to base material $\mathrm{C} / \mathrm{C}$ composite) and decreased tensile strength $(-77 \%$ to base material $\mathrm{C} / \mathrm{C}$ composite).

\section{Discussion}

\subsection{Discussion (Observation of a State of Three-Dimensional Structural Trunk/Branch Matrix)}

Since there exists a phenomenon that the bending/tensile strength of the $\mathrm{Si}-\mathrm{SiC}$ matrix $\mathrm{C} / \mathrm{C}$ composite are decreased as against the base material $\mathrm{C} / \mathrm{C}$ composite, the factors are observed and examined from a standpoint of three-dimensional structural trunk/branch matrix.

Figures 4 and 5 show the result of observation of a state that three-dimensional structure of the Si-SiC matrix or $\mathrm{Cu}$ matrix is distributed. Here, Figure 4 [A1] is an optical micrograph taken after polishing the Y-Z surface (Figure 3) of the $\mathrm{Si}-\mathrm{SiC}$ matrix $\mathrm{C} / \mathrm{C}$ composite with \#800 grinding stone, and Figure 4 [A2] is an optical micrograph taken after retaining the state of [A1] in the air at $880^{\circ} \mathrm{C}$ for one hour to remove carbon constituent. In addition, Figure $5[\mathrm{~B} 1]$ is an optical micrograph after polishing the $\mathrm{Y}-\mathrm{Z}$ surface of the $\mathrm{Cu}$ matrix $\mathrm{C} / \mathrm{C}$ composite with \#800 grinding stone, and Figure 5 [B2] is an optical micrograph taken after retaining the state of [B1] in the air at $880^{\circ} \mathrm{C}$ for one hour to remove carbon constituent. It should be noted that a possibility for removing carbon constituent by heating at $880^{\circ} \mathrm{C}$ in the air is confirmed from thermogravimetry (Figure 6 ) of carbon powder of raw material of the base material $\mathrm{C} / \mathrm{C}$ composite and carbon fiber.

The $\mathrm{Si}-\mathrm{SiC}$ matrix $\mathrm{C} / \mathrm{C}$ composite is a dense composite material (Hanzawa, 2012) obtained by performing $\mathrm{Si}$ impregnation at base points of pores at intervals of about $300 \mu \mathrm{m}$ in the base material $\mathrm{C} / \mathrm{C}$ composite to synthesize three-dimensional trunk/branch $\mathrm{Si}-\mathrm{SiC}$ matrix in the base material $\mathrm{C} / \mathrm{C}$ composite. This material structure can also be understood from the state (Figure 4 [A1], [A2]) that a three-dimensional structure trunk/branch $\mathrm{Si}-\mathrm{SiC}$ matrix is distributed over the base material $\mathrm{C} / \mathrm{C}$ composite. The same structure is also found in the $\mathrm{Cu}$ matrix $\mathrm{C} / \mathrm{C}$ composite (Figure 5 [B1] and [B2]) in which three-dimensional structural trunk/branch matrix $\mathrm{Cu}$ is distributed in the base material $\mathrm{C} / \mathrm{C}$ composite.

From this point, it is considered that structure of the three-dimensional structural trunk/branch matrix itself is not a direct factor in reducing the $\mathrm{C} / \mathrm{C}$ composite properties.

Furthermore, comparing Figure 4 [A2] with Figure 5 [B2], both trunk matrix/branch matrix of [A2] in which a part of carbon constituent is used for matrix synthesis grow more thickly than [B2] in which carbon constituent is not consumed at the time of matrix synthesis, as a result, [A2] has smaller pores after removing carbon fiber yarns. This indicates the relationship between [A1] and [B1], the percentage of carbon constituent in [A1] is 12 Vol.\% less than [B1] (ratio of constituents of the $\mathrm{Si}-\mathrm{SiC}$ matrix $\mathrm{C} / \mathrm{C}$ composite is "carbon constituent vs. Si-SiC $=74 \mathrm{vol} \%$ vs. $26 \mathrm{vol} \%$ " from the publication (Hanzawa, 2012). The ratio of constituents of the $\mathrm{Cu}$ matrix $\mathrm{C} / \mathrm{C}$ composite is "carbon constituent vs. $\mathrm{Cu}=86 \mathrm{vol} \%$ vs. $14 \mathrm{vol} \%$ " from bulk density data in Table 1 and $\mathrm{Cu}$ 's theoretical density $8.9 \mathrm{~g} / \mathrm{cc})$. However, this does not lead to an explanation of large divergence from a ratio (-54\% to $-77 \%$ ) that bending/tensile strength of the $\mathrm{Si}-\mathrm{SiC}$ matrix $\mathrm{C} / \mathrm{C}$ composite decreased compared to the base material $\mathrm{C} / \mathrm{C}$ composite. From this point, it is also considered that the structure of three-dimensional structural trunk/branch matrix itself is not a direct factor in reducing bending/tensile strength properties of the base material $\mathrm{C} / \mathrm{C}$ composite.

\subsection{Discussion (Mechanical Properties Evaluation with the Use of Complex Rules)}

When the $\mathrm{Si}-\mathrm{SiC}$ matrix is synthesized in the base material $\mathrm{C} / \mathrm{C}$ composite, bending/tensile strength is decreased largely $(-54 \%$ to $-77 \%)$ as against reduction of carbon constituent $(-12 \%)$. On the contrary, when the $\mathrm{Cu}$ matrix is synthesized in the base material $\mathrm{C} / \mathrm{C}$ composite, there is no change of carbon constituent $(-0 \%)$ and reduction of bending/tensile strength is not recognized. A relation of this value of strength is examined from a standpoint of complex rules that considers dispersion and orientation of fibers in the composite.

Formulas 1, 2 and 3 are enumerated for complex rules for calculating characteristic values of composite comprising a dual-element simple system base material and a matrix (Kagawa et al., 1990).

$$
\begin{gathered}
P_{c}=P_{m} V_{m}+\left(1-V_{m}\right) P_{f} \\
\ln P_{c}=V_{m} \ln P_{m}+\left(1-V_{m}\right) \ln P_{f} \\
1 / P_{c}=V_{m} / P_{m}+\left(1-V_{m}\right) / P_{f}
\end{gathered}
$$

Here in, $P_{c}=$ Characteristic values of composite, $P_{f}=$ Characteristic values of base materials, 
$P_{m}=$ Characteristic values of matrix, $V_{m}=$ Volume fraction of matrix.

Formula 1 is a complex rule of elastic modulus, Poisson's ratio, strength, thermal conductivity and electric conductivity in the direction of fiber axis when the base material is unidirectional fiber reinforced material. Formula 2 is a complex rule of estimation of elastic modulus and dielectric constant when the base material is spherical particle dispersion, elastic modulus when base material is irregular structure, and elastic modulus and thermal conductivity when base material is three-dimensional random oriented material. Formula 3 is a complex rule of elastic modulus, dielectric constant, thermal conductivity and electric conductivity in the direction perpendicular to the fiber axis when the base material is unidirectional fiber reinforced material (Kagawa, et al., 1990). Here, a characteristic value common to these three formulas is elastic modulus.

Accordingly, a relationship was established among bending elastic modulus ( $35 \pm 6 \mathrm{GPa}$, Table 1)of the base material $\mathrm{C} / \mathrm{C}$ composite, and bending elastic modulus obtained from complex rules using bending elastic modulus of the $\mathrm{Si}-\mathrm{SiC}$ matrix in consideration of "the use of NEWSIC's value ( $352 \mathrm{GPa} \pm 30$ ) for bending elastic modulus of the $\mathrm{Si}-\mathrm{SiC}$ matrix. Herein, volume ratio of $\mathrm{Si}$ and $\mathrm{SiC}$ in the $\mathrm{Si}-\mathrm{SiC}$ matrix $\mathrm{C} / \mathrm{C}$ composite is $\mathrm{Si}: \mathrm{SiC}=17: 83 \mathrm{Vol} \%$ from the publication (Hanzawa, 2012) and close to volume ratio of $\mathrm{Si}$ and $\mathrm{SiC}$ ( $\mathrm{Si}: \mathrm{SiC}=18: 82 \mathrm{Vol} . \%$ ) of commercially available $\mathrm{Si}-\mathrm{SiC}$ composite (NEWSIC made by NGK, Hanzawa et al.,1996)". Actual measurement value (42 $\pm 13 \mathrm{GPa}$, Table 1) of bending elastic modulus of the $\mathrm{Si}-\mathrm{SiC}$ matrix C/C composite was compared.

The result is shown in Figure 7. In addition, calculations were made with volume ratio of the Si-SiC matrix portion of the $\mathrm{Si}-\mathrm{SiC}$ matrix $\mathrm{C} / \mathrm{C}$ composite considered as $26 \mathrm{Vol} . \%$ (refer to 4.1).

Similarly, relation among tensile elastic modulus $(54.1 \pm 10 \mathrm{GPa}$, Table 1$)$ of the base material $\mathrm{C} / \mathrm{C}$ composite, tensile elastic modulus of calculated according to complex rules using the published value (129.8 GPa, (Wang, et al., 2008)) of tensile elastic modulus of the $\mathrm{Cu}$ matrix, and actual measurement value (62.5 $\pm 14 \mathrm{GPa}$, Table 1$)$ of tensile elastic modulus of the $\mathrm{Cu}$ matrix $\mathrm{C} / \mathrm{C}$ composite was compared. The result is shown in Figure 8. In addition, calculations were made with volume amount of the $\mathrm{Cu}$ matrix portion of the $\mathrm{Cu}$ matrix $\mathrm{C} / \mathrm{C}$ composite considered as $14 \mathrm{Vol} \%$ (refer to 4.1 ).

It is found from Figure 7 that the actual measurement value (including distribution) of bending elastic modulus of the $\mathrm{Si}-\mathrm{SiC}$ matrix $\mathrm{C} / \mathrm{C}$ composite coincides with calculation values according to Formula 3 of complex rules and partly coincides with calculations according to Formula 2. Furthermore, it is found from Figure 8 that the actual measurement value (including distribution) of tensile elastic modulus of the $\mathrm{Cu}$ matrix $\mathrm{C} / \mathrm{C}$ composite coincides with any of the calculations according to Formulas $1 / 2 / 3$ of complex rules. From this, it can be said that elastic modulus of the $\mathrm{Si}-\mathrm{SiC}$ matrix $\mathrm{C} / \mathrm{C}$ composite and the $\mathrm{Cu}$ matrix $\mathrm{C} / \mathrm{C}$ composite indicates the property that coincides with complex rules.

Next, examination by means of complex rules was performed for strength of the $\mathrm{C} / \mathrm{C}$ composite of the $\mathrm{Si}-\mathrm{SiC}$ matrix and the $\mathrm{Cu}$ matrix. Here, although complex rules to be applied to strength is Formula 1, calculations according to Formulas 2 and 3 were also performed for comparison.

Figure 9 shows the result of comparing a relation among bending strength $(240 \pm 16 \mathrm{MPa}$, Table 1$)$ of the base material $\mathrm{C} / \mathrm{C}$ composite, bending strength calculated according to complex rules using bending strength of the $\mathrm{Si}-\mathrm{SiC}$ matrix (in consideration of the use of bending strength $(240 \mathrm{MPa} \pm 21)$ of NEWSIC made by NGK according to way of thinking of bending elastic modulus), and actual measurement value (111 $\pm 16 \mathrm{MPa}$, Table 1) of bending strength of the $\mathrm{Si}-\mathrm{SiC}$ matrix $\mathrm{C} / \mathrm{C}$ composite.

Figure 10 shows the result of comparing a relation among tensile strength $(238.7 \pm 19 \mathrm{MPa}$, Table 1$)$ of the base material $\mathrm{C} / \mathrm{C}$ composite, tensile strength calculated according to complex rules using the published value (216 $\mathrm{MPa}$, (Wang, et al., 2008)) of tensile strength of the $\mathrm{Cu}$ matrix, and actual measurement value $(279.4 \pm 15 \mathrm{GPa}$, Table 1) of tensile strength of the $\mathrm{Cu}$ matrix $\mathrm{C} / \mathrm{C}$ composite.

In Figure 9, with regards to actual measurement value (including distribution) of bending strength of the $\mathrm{Si}-\mathrm{SiC}$ matrix C/C composite, percentage of coincidence with calculations according to Formulas $1 / 2 / 3$ is $58 \%$ or less (divergence minimum portion $=137 \mathrm{MPa}$ (actual measurement value) $/ 235 \mathrm{MPa}$ (complex rules) $=58 \%$ ), it can be said that this is a material difficult to explain according to complex rules. On the contrary, as shown in Figure 10, with regard to actual measurement value (including distribution) of tensile strength of the $\mathrm{Cu}$ matrix $\mathrm{C} / \mathrm{C}$ composite, percentage of coincidence with calculations according to any of the Formulas $1 / 2 / 3$ is $85 \%$ or more (divergence maximum portion=224 MPa (complex rules)/264.4 MPa (actual measurement value)), and therefore it is considered that this material has the property in conformity to complex rules.

Here, measured strength of the $\mathrm{Si}-\mathrm{SiC}$ matrix $\mathrm{C} / \mathrm{C}$ composite as shown in Figure 9 diverges from calculated 
strength by complex rules, and therefore cause of behavior greatly degraded against strength performance of the base material $\mathrm{C} / \mathrm{C}$ composite is examined at the same time. Figure 11 shows microstructure near the boundary of the $\mathrm{Si}-\mathrm{SiC}$ matrix portion and the carbon fiber yarn of the base material $\mathrm{C} / \mathrm{C}$ composite and gradient of concentration of $\mathrm{Si}$ and $\mathrm{C}$ constituents at this portion. It is found from Figure 11 that the surface of the carbon fiber in a range where $\mathrm{Si}$ and $\mathrm{C}$ coexist is intensely uneven and smooth surface of the carbon fiber is broken. At the same time, there also exist cracks from the $\mathrm{Si}$-SiC matrix region extending to the inside of the carbon fiber yarn. This phenomenon suggests that the carbon constituent which reacts with $\mathrm{Si}$ and is converted to $\mathrm{SiC}$ remains at $12 \mathrm{Vol} \% \%$ and that the carbon fiber yarn of volume of $12 \mathrm{Vol} . \%$ or more is damaged.

Figure 12 shows the result of examining an amount of the damaged carbon fiber yarn using complex rules. In addition, although for estimated calculation of strength, applying Formula 1 of complex rules is in conformity to the way of thinking of the formula, there is a tendency that calculation values with Formulas 1/2/3 for estimated calculation (Figure 10) of tensile strength of the $\mathrm{Cu}$ matrix $\mathrm{C} / \mathrm{C}$ composite coincide with actual measurement values, and therefore examination is performed using three formulas. In Figure 12, with volume of carbon constituent of the $\mathrm{Si}-\mathrm{SiC}$ matrix $\mathrm{C} / \mathrm{C}$ composite, the carbon constituent of which is reduced (12 Vol.\%) due to $\mathrm{Si}-\mathrm{SiC}$ matrix synthesizing, taken as $100 \%$, on the assumption that volume of carbon constituent contributing to development of strength is reduced to a range from $11 \%$ (Formula 1) to $47 \%$ (Formula 3), it is possible to calculate that strength property of the $\mathrm{Si}-\mathrm{SiC}$ matrix $\mathrm{C} / \mathrm{C}$ composite coincides with complex rules.

Consequently, reduction of bending/tensile strength $(111 \mathrm{MPa} / 55 \mathrm{MPa}$, Table 1) of the $\mathrm{Si}-\mathrm{SiC}$ matrix $\mathrm{C} / \mathrm{C}$ composite against bending/tensile strength $(240 \mathrm{MPa} / 239 \mathrm{MPa}$, Table 1$)$ of the base material $\mathrm{C} / \mathrm{C}$ composite is an unavoidable phenomenon at the time of synthesizing the $\mathrm{Si}-\mathrm{SiC}$ matrix, and therefore wisdom and ingenuity are required to design structural components, which maintain and improve the properties of the base material $\mathrm{C} / \mathrm{C}$ composite, using the $\mathrm{Si}-\mathrm{SiC}$ matrix $\mathrm{C} / \mathrm{C}$ composite, as bending/tensile strength (248 MPa/279 MPa, Table 1) of the $\mathrm{Cu}$ matrix $\mathrm{C} / \mathrm{C}$ composite.

\subsection{Discussion (Application Example to Practical Use)}

Advantage of the properties of the $\mathrm{Si}-\mathrm{SiC}$ matrix $\mathrm{C} / \mathrm{C}$ composite to the properties of the base material $\mathrm{C} / \mathrm{C}$ composite is an increase of compressive strength, and drawback is a decrease of bending/tensile strength (refer to Table 1). Furthermore, sections 4.1 and 4.2 consider that this drawback (decrease of bending/tensile strength) is an unavoidable phenomenon when the $\mathrm{Si}-\mathrm{SiC}$ matrix accompanied by $\mathrm{SiC}$ synthesizing reaction is used for the matrix inside of the $\mathrm{C} / \mathrm{C}$ composite. In view of these backgrounds, the author considers it necessary to innovate "structural component design by configuring with the $\mathrm{Si}-\mathrm{SiC}$ matrix converted $\mathrm{C} / \mathrm{C}$ composite for the portions receiving compressive stress and configuring with the $\mathrm{C} / \mathrm{C}$ composite for the portions receiving bending/tensile stress" when designing structural components which use the $\mathrm{Si}-\mathrm{SiC}$ matrix $\mathrm{C} / \mathrm{C}$ composite for alternative material of the $\mathrm{C} / \mathrm{C}$ composite. Accordingly, a fracture experimental method (refer to Figure 13) for applying loads at crosshead speed of $0.5 \mathrm{~mm} / \mathrm{min}$ in the direction (Y-axis) of tearing a notch of 32x11 $\mathrm{mm}$ (R4) provided centering the X-axis short portion of the material with outside size of $40 / 80 / 10 \mathrm{~mm}$ of $\mathrm{X}-/ \mathrm{Y}-/ \mathrm{Z}$-axis is used to examine effectiveness of author's way of thinking. The results of fracture experiment are indicated in Figure 14 (where, C0 indicates a state of the base material C/C composite (Chang, Nakagawa \& Okura, 1991) after experiment, $\mathrm{C} 1 \mathrm{X}$ is an $\mathrm{X}$-ray photo of the $\mathrm{C} / \mathrm{C}$ composite (Hanzawa, 2012) by synthesizing the $\mathrm{Si}-\mathrm{SiC}$ matrix all over the $\mathrm{C} / \mathrm{C}$ composite before experiment (densified portion by $\mathrm{Si}$ impregnation is shown white), $\mathrm{C} 1$ indicates a state after experiment, $\mathrm{C} 2 \mathrm{X}$ is an $\mathrm{X}$-ray photo of partial $\mathrm{Si}-\mathrm{SiC}$ matrix $\mathrm{C} / \mathrm{C}$ composite (Hanzawa \& Hashimoto, 2010) by synthesizing the $\mathrm{Si}-\mathrm{SiC}$ matrix partially on the $\mathrm{C} / \mathrm{C}$ composite before experiment (densified portion by $\mathrm{Si}$ impregnation is shown white), $\mathrm{C} 2$ indicates a state after experiment ). Here, the $\mathrm{C} 2$ specimen has three holes of $0.5 \mathrm{~mm}$ in diameter indicated in the $\mathrm{C} 2 \mathrm{X}$ and is prepared from these holes through the use of a method (Hanzawa \& Hashimoto, 2010) of performing the Si impregnation, portions around three holes and periphery of the specimen are densified by Si impregnation and recognized in white in the X-ray photo. Table 2 shows the breaking loads of these specimens and the result of processing specimens of $X: Y: Z=10: 10: 10 \mathrm{~mm}$ from four corner ends and measuring compressive strength with regard to partial $\mathrm{Si}-\mathrm{SiC}$ matrix $\mathrm{C} / \mathrm{C}$ composite.

When comparing fracture morphology of thee kinds of materials indicated in Figure 14, there exists interlaminar /shear fracture at portions getting contact with a jig for $\mathrm{C} 0$ and no fracture at portions of contact for $\mathrm{C} 1$ and $\mathrm{C} 2$. Although it is considered that such interlaminar/shear fracture is attributable to compressive stress at portions having contact with the jig, with regards to compressive strength, which is also the result of effectively utilizing the properties (Table 1) of the $\mathrm{Si}-\mathrm{SiC}$ matrix $\mathrm{C} / \mathrm{C}$ composite superior to the $\mathrm{C} / \mathrm{C}$ composite. Furthermore, when comparing fracture sections of $\mathrm{C} 1$ and $\mathrm{C} 2, \mathrm{C} 2$ has long traces extracting carbon fibers of about $10 \mathrm{~mm}$, and $\mathrm{C} 1$ has short traces extracting carbon fibers of about $2 \mathrm{~mm}$. It is considered that this difference in length links to difference in breaking load of these three kinds of materials: "as against breaking load (100\%) of the base 
material $\mathrm{C} / \mathrm{C}$ composite, breaking load of the $\mathrm{Si}-\mathrm{SiC}$ matrix $\mathrm{C} / \mathrm{C}$ composite is reduced to $65 \%$, but breaking load of partial $\mathrm{Si}-\mathrm{SiC}$ matrix $\mathrm{C} / \mathrm{C}$ composite remains $93 \%$ (Table 2)". In other words, it can be said that partial Si-SiC matrix $\mathrm{C} / \mathrm{C}$ composite is effective material design technique against maintenance of advantage and improvement of drawback of the base material $\mathrm{C} / \mathrm{C}$ composite.

\section{Conclusions}

1). The cause of greatly decreasing bending/tensile strength of the $\mathrm{Si}-\mathrm{SiC}$ matrix $\mathrm{C} / \mathrm{C}$ composite as against the $\mathrm{C} / \mathrm{C}$ composite is not subjected to trunk/branch three-dimensional matrix structure stemming from densified composite, but is attributable to the fact that $50 \%$ or more of the carbon fiber yarn structure is broken when 12 Vol.\% of carbon constituent in the base material $\mathrm{C} / \mathrm{C}$ composite is converted to $\mathrm{SiC}$, and therefore is an unavoidable phenomenon during the synthesizing process of dense $\mathrm{Si}-\mathrm{SiC}$ matrix $\mathrm{C} / \mathrm{C}$ composite.

2). To maintain the advantage of strength of the base material $\mathrm{C} / \mathrm{C}$ composite and simultaneously to improve the drawback of strength, the following structural component design using the $\mathrm{Si}-\mathrm{SiC}$ matrix $\mathrm{C} / \mathrm{C}$ composite is effective. This is a partial $\mathrm{Si}-\mathrm{SiC}$ matrix $\mathrm{C} / \mathrm{C}$ composite that produces the $\mathrm{Si}-\mathrm{SiC}$ matrix structure for portions where compressive stress occurs and that does not produce the $\mathrm{Si}-\mathrm{SiC}$ matrix structure for portions where bending/tensile stress occurs, rather than the structure of synthesizing the $\mathrm{Si}-\mathrm{SiC}$ matrix all over the $\mathrm{C} / \mathrm{C}$ composite.

\section{Acknowledgements}

The author thanks to Mr. T. Mizutani, Mr. T. Mizuno, Mr. T. Inaba and Mr. H. Fukui, Directors of NGK Ins., for their kind permission to publish this article. The author also thanks Dr. T. Ohta, Dr. N. Ishizawa, Professors of Nagoya Institute of Technology and Dr. H. N. Ko, Professor of Nakanihon Automotive College, for their advice in preparation of this article. The author also thanks to Mr. N. Hashimoto for his efforts in mechanical experiments. Lastly, thanks to Mr. Jim V. Castle for proof reading of final document.

\section{References}

Brandes, E. A., \& Brook, G. B., (eds). (1992). Smithells Metals Reference Book, $7^{\text {th }}$ edition. ButterworthHeinemann, Oxford, Table15.1, Table22.7.

Chang, T., Nakagawa, T., \& Okura, A., (1991). Studies on a New Manufacturing Process of Carbon Fiber Reinforced Carbon Matrix(C/C) Composites. Report of institute of industrial science, Tokyo University, 35(8), Ser.229, UDC 621.762.41.5: 669-419.8: 677.5:662.749.2.

Evans, C. C., Parmee, A. C., \& Rainbird, R. W. (1976). Carbon Fibre/Carbon Composite Materials Impregnated With Silicon. GB-Patent, 1457757.

Fitzer, E., (1987). In: Soumiya S, Moriyoshi Y (eds) SHOUKETSU-case study. Uchida Roukakuho publishing, Tokyo, p43.

Hanzawa, S. (2012). Mechanism of synthesizing dense Si-SiC matrix C/C composites. Journal of Materials Science, 47, 833-844. http://dx.doi.org/10.1007/s10853-011-5861-5

Hanzawa, S., \& Hashimoto, N. (2010). JP-Patent, 4464552 (in Japanese).

Hanzawa, S., \& Ishikawa, S. (2003). JP-Patent, 3478737 (in Japanese).

Hanzawa, S., \& Komiyama, T. (1996). JP-Patent, 2535480 (in Japanese).

Hanzawa, S., \& Nakagawa, T. (2002). Fiber-composite material and its use. EP-Patent, 0926111B2.

Hanzawa, S., \& Nakagawa, T., (2003). JP-Patent, 3491902 (in Japanese).

Hanzawa, S., (2005). A member for Brakes. EP-Patent, 0985647B1.

JIS R 1644, (2002). Testing methods for elastic modulus of continuous fiber-reinforced ceramic matrix composites, Japanese Standards Association.

JIS R 1663, (2004). Testing method for flexural strength of continuous fiber-reinforced ceramic matrix composites, Japanese Standards Association.

JIS R 1673, (2007). Test method for compressive behavior of continuous fiber-reinforced ceramic matrix composites at room temperature. Japanese Standards Association.

Kagawa, Y., \& Hatta, H. (1990). Tailoring Ceramic Composites. Agune Syoufu-sha publishing, Table 5.1.

Popper, P. (1961). Improvements relating to the production of Dense Bodies of Silicon Carbide. GB-Patent, 866813. 
Wang, W. X., Takao, Y., \& Matsubara, T. (2008). Tensile strength and fracture toughness of C/C and metal infiltrated composites Si-C/C and Cu-C/C. Composites Part A: Applied Science and Manufacturing, 39, 231-242. http://dx.doi.org/10.1016/j.compositesa.2007.11.004

Wrzesien, A. P., Whitney, I., \& Katona, J. (1976). Carbon Fiber Composites, US-Patent, 3994762

Table 1. Mechanical property of $\mathrm{C} / \mathrm{C}$ composite, $\mathrm{Si}-\mathrm{SiC}$ matrix $\mathrm{C} / \mathrm{C}$ composite and $\mathrm{Cu}$ matrix $\mathrm{C} / \mathrm{C}$ composite

\begin{tabular}{|l|c|c|c|l|}
\hline & $\begin{array}{c}\mathrm{C} / \mathrm{C} \text { composite } \\
\text { (Base material) }\end{array}$ & $\begin{array}{c}\text { Si-SiC matrix } \\
\mathrm{C} / \mathrm{C} \text { composite }\end{array}$ & $\begin{array}{c}\text { Cu matrix C/C } \\
\text { composite }\end{array}$ & $\begin{array}{l}\text { N.B. } \\
\text { Test method }\end{array}$ \\
\hline Bulk density & $1.65 \mathrm{~g} / \mathrm{cc}$ & $2.05 \mathrm{~g} / \mathrm{cc}$ & $2.50 \mathrm{~g} / \mathrm{cc}$ & Archimedes method \\
\hline Porosity & $16.1 \mathrm{Vol} \%$ & $3.5 \mathrm{Vol} \%$ & $2.5 \mathrm{Vol} \%$ & \multicolumn{1}{c|}{ Ibid } \\
\hline $\begin{array}{l}\text { Compressive strength } \\
\text { Average value }\end{array}$ & $129 \pm 31 \mathrm{MPa}$ & $265 \pm 45 \mathrm{MPa}$ & $243 \pm 19 \mathrm{MPa}$ & $\begin{array}{l}\text { Test is based on } \\
\text { JIS R1673(2007) }\end{array}$ \\
\hline $\begin{array}{l}\text { Bending strength } \\
\text { Average value }\end{array}$ & $240 \pm 16 \mathrm{MPa}$ & $111 \pm 26 \mathrm{MPa}$ & $248 \pm 21 \mathrm{MPa}$ & $\begin{array}{l}\text { Test is based on } \\
\text { JIS R 1663(2004) }\end{array}$ \\
\hline $\begin{array}{l}\text { Bending elastic modulus } \\
\text { Average value }\end{array}$ & $35 \pm 6 \mathrm{GPa}$ & $42 \pm 13 \mathrm{GPa}$ & $105 \pm 16 \mathrm{GPa}$ & $\begin{array}{l}\text { Test is based on } \\
\text { JIS R 1644(2002) }\end{array}$ \\
\hline $\begin{array}{l}\text { Tensile strength } \\
\text { Average value }\end{array}$ & $238.7 \pm 19 \mathrm{MPa}$ & $55.4 \pm 7 \mathrm{MPa}$ & $279.4 \pm 15 \mathrm{MPa}$ & $\begin{array}{l}\text { Data's taken from } \\
\text { Wang } \text { et al. } \text { (2008) }\end{array}$ \\
\hline $\begin{array}{l}\text { Tensile elastic modulus } \\
\text { Average value }\end{array}$ & $54.1 \pm 10 \mathrm{GPa}$ & $57.8 \pm 10 \mathrm{GPa}$ & $62.5 \pm 14 \mathrm{GPa}$ & $\begin{array}{l}\text { Datas taken from } \\
\text { Wang } \text { et al. } \text { (2008) }\end{array}$ \\
\hline
\end{tabular}

Table 2. Breaking load of $\mathrm{C} / \mathrm{C}$ composite, $\mathrm{Si}-\mathrm{SiC}$ matrix $\mathrm{C} / \mathrm{C}$ composite and partial $\mathrm{Si}-\mathrm{SiC}$ matrix $\mathrm{C} / \mathrm{C}$ composite

\begin{tabular}{|l|c|c|c|l|}
\hline & $\begin{array}{c}\text { C/C composite } \\
\text { (Base material) }\end{array}$ & $\begin{array}{c}\text { Si-SiC matrix } \\
\text { C/C composite }\end{array}$ & $\begin{array}{c}\text { Partially } \\
\text { Si-SiC matrix } \\
\text { C/C composite }\end{array}$ & $\begin{array}{l}\text { N.B. } \\
\text { Test method }\end{array}$ \\
\hline $\begin{array}{l}\text { Breaking load } \\
\text { Average value [kgf] }\end{array}$ & $217 \pm 21 \mathrm{kgf}$ & $142 \pm 15 \mathrm{kgf}$ & $202 \pm 28 \mathrm{kgf}$ & $\begin{array}{l}\text { Written in Figure } \\
13\end{array}$ \\
\hline Breaking load ratio [\%] & $100 \%$ & $65 \%$ & $93 \%$ & --- \\
\hline $\begin{array}{l}\text { Compressive strength } \\
\text { Average value [MPa] }\end{array}$ & $\begin{array}{c}129 \pm 27 \mathrm{MPa} \\
\text { (From Table 1) }\end{array}$ & $\begin{array}{c}265 \pm 24 \mathrm{MPa} \\
\text { (From Table 1) }\end{array}$ & $\begin{array}{c}218 \pm 30 \mathrm{MPa} \\
\text { (Samples cut from } \\
\text { edge portion) }\end{array}$ & $\begin{array}{l}\text { Test is based on } \\
\text { JIS R1673(2007) }\end{array}$ \\
\hline
\end{tabular}

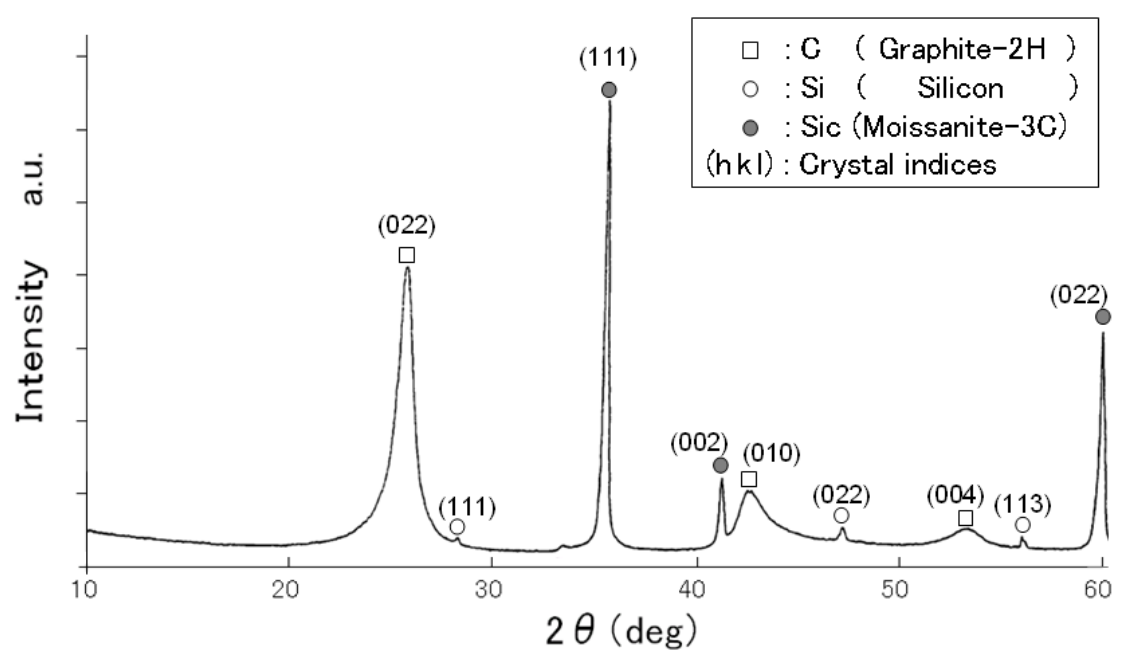

Figure 1. Result of $\mathrm{X}$-ray diffraction of $\mathrm{Si}-\mathrm{SiC}$ matrix $\mathrm{C} / \mathrm{C}$ composite 


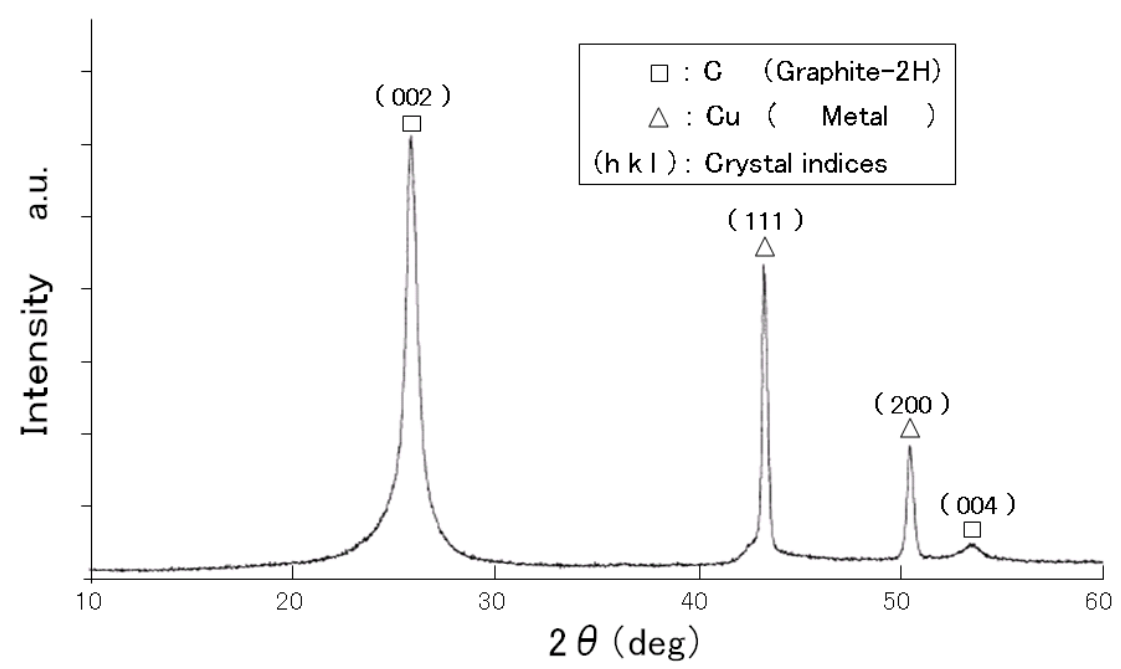

Figure 2. Result of $\mathrm{X}$-ray diffraction of $\mathrm{Cu}$ matrix $\mathrm{C} / \mathrm{C}$ composite

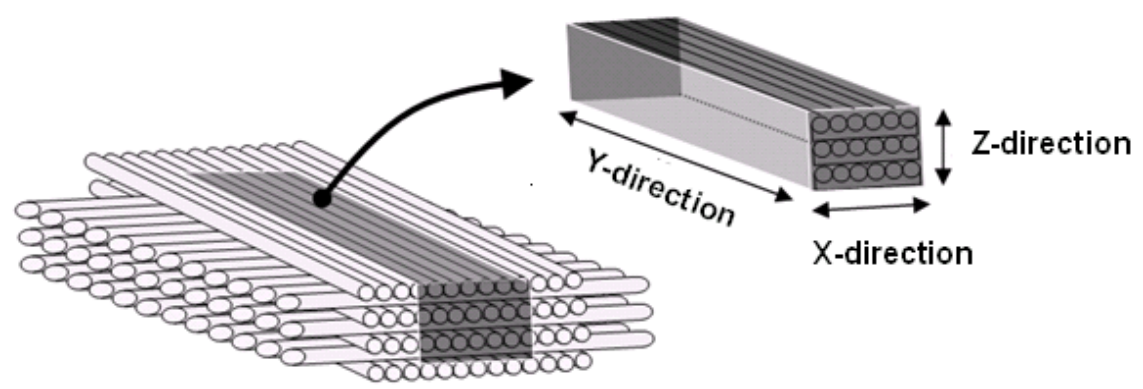

Figure 3. Direction of processing of test specimen from composite containing carbon fiber yarn and sheet
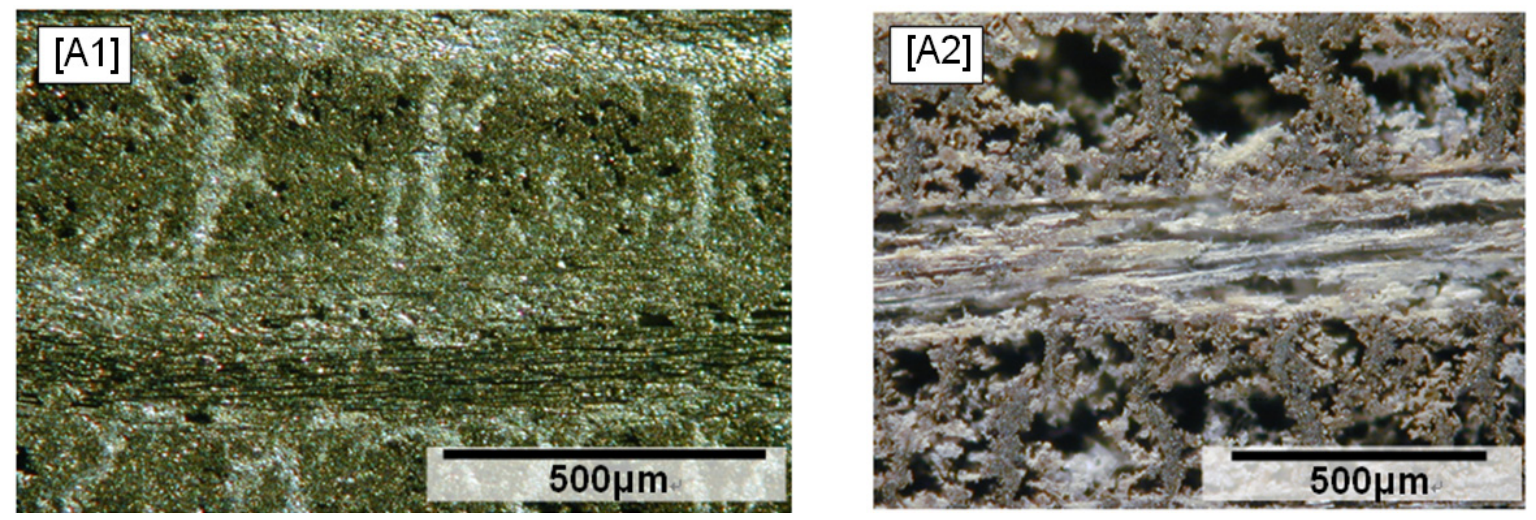

Figure 4. Optical micrograph of $\mathrm{Si}-\mathrm{SiC}$ matrix $\mathrm{C} / \mathrm{C}$ composite

[A1] shows the surface of a material polished by $\# 800$ grinding stone

[A2] shows the surface of $\mathrm{A} 1$ after retaining in the air at $880^{\circ} \mathrm{C}$ for 1 hour 

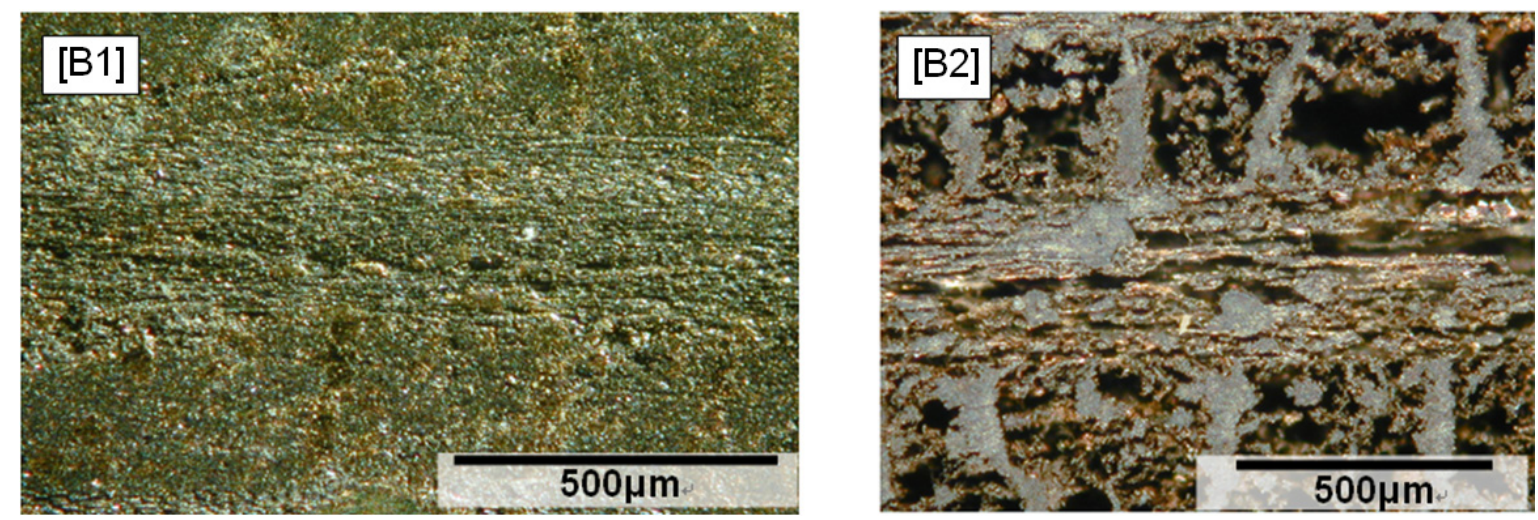

Figure 5. Optical micrograph of $\mathrm{Cu}$ matrix $\mathrm{C} / \mathrm{C}$ composite

[B1] shows the surface of a material polished by $\# 800$ grinding stone

[B2] shows the surface of $\mathrm{B} 1$ after retaining in the air at $880^{\circ} \mathrm{C}$ for 1 hour

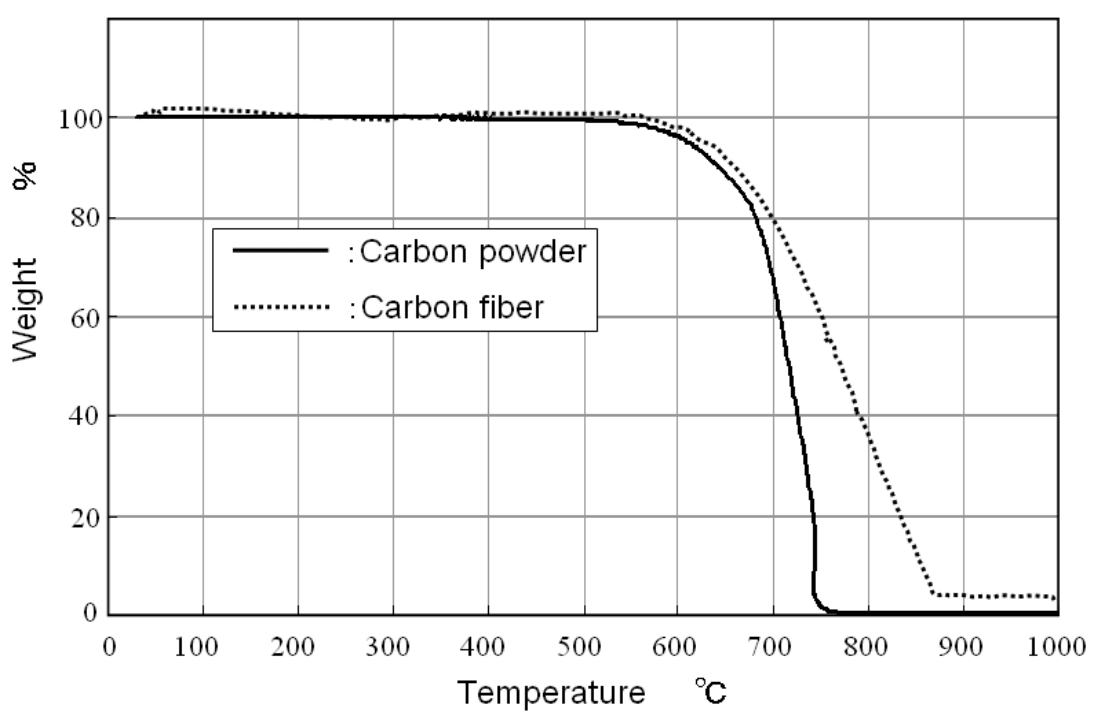

Figure 6. Thermo-gravity of carbon powder and carbon fiber used for $\mathrm{C} / \mathrm{C}$ composite (AC200) Measurement conditions : in the air, temperature rising speed $10^{\circ} \mathrm{C} / \mathrm{min}$ 


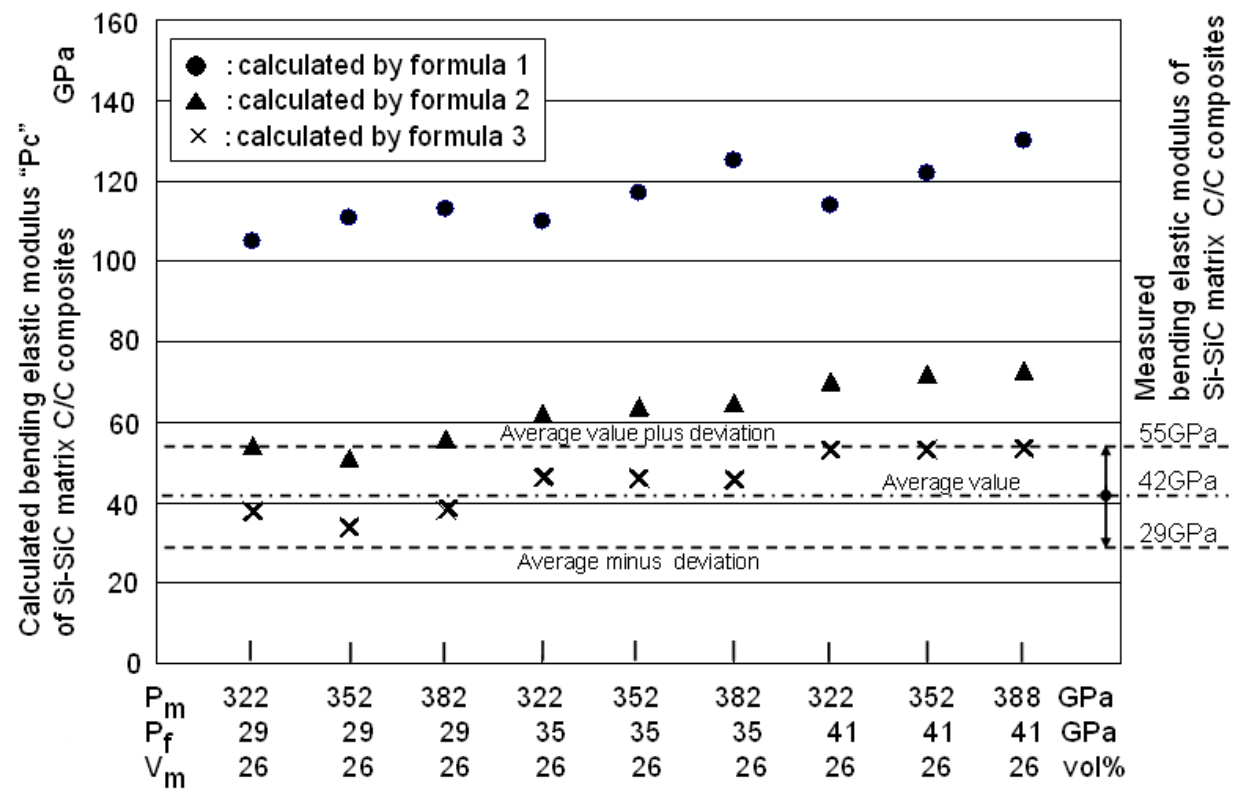

Figure 7. Relation between bending elastic modulus $P_{c}$ of the $\mathrm{Si}-\mathrm{SiC}$ matrix $\mathrm{C} / \mathrm{C}$ composite and actual measurement value using complex rules

Herein, $P_{f}=$ Characteristic values $(35 \pm 6 \mathrm{GPa})$ of base material $\mathrm{C} / \mathrm{C}$ composite

$P_{m}=$ Characteristic values $(352 \pm 30 \mathrm{GPa})$ of $\mathrm{Si}-\mathrm{SiC}$ matrix $V_{m}=$ Volume ratio (26 Vol.\%) of $\mathrm{Si}-\mathrm{SiC}$ matrix.

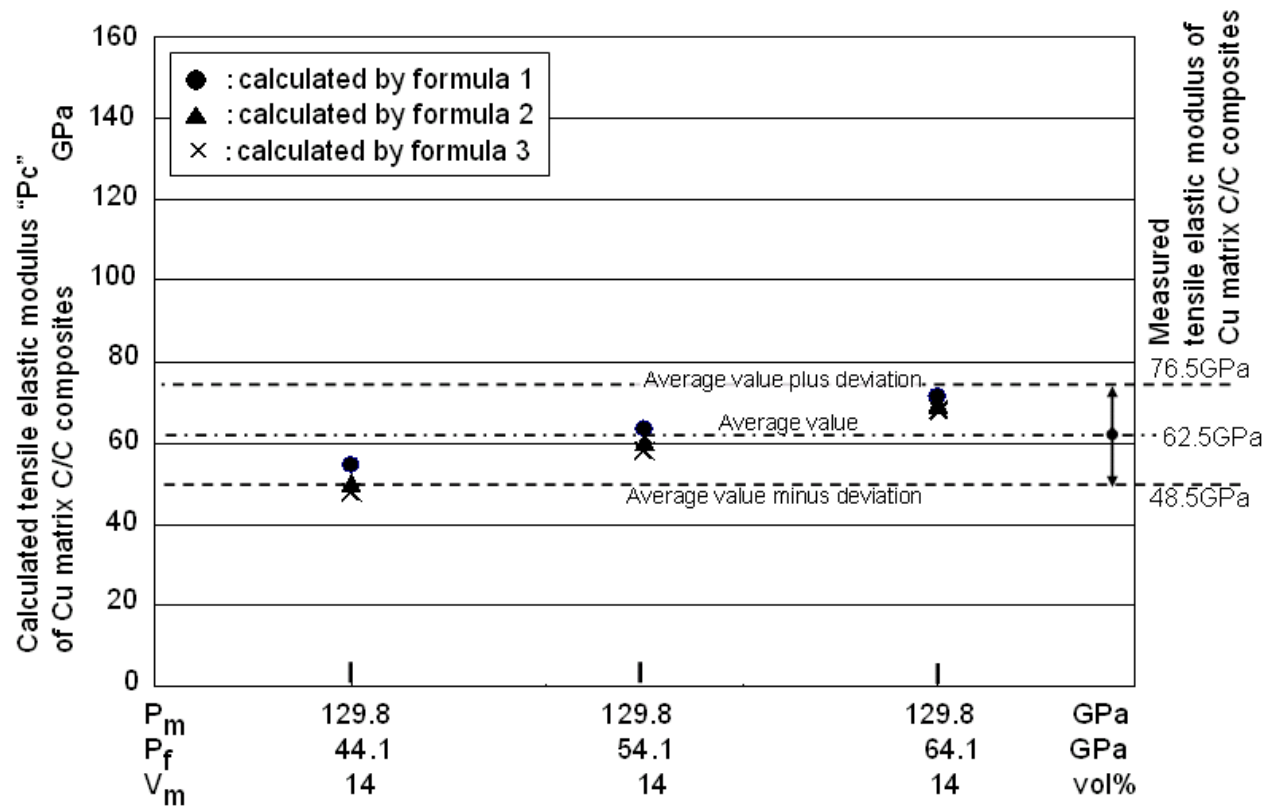

Figure 8. Relation between tensile elastic modulus $P_{c}$ of the $\mathrm{Cu}$ matrix $\mathrm{C} / \mathrm{C}$ composite and actual measurement value using complex rules

Herein, $P_{f}=$ Characteristic values $(54.1 \pm 10 \mathrm{GPa})$ of base material $\mathrm{C} / \mathrm{C}$ composite

$P_{m}=$ Characteristic values $(129.8 \mathrm{GPa})$ of $\mathrm{Cu}$ matrix

$V_{f}=$ Volume ratio $(14 \mathrm{Vol} . \%)$ of $\mathrm{Cu}$ matrix. 


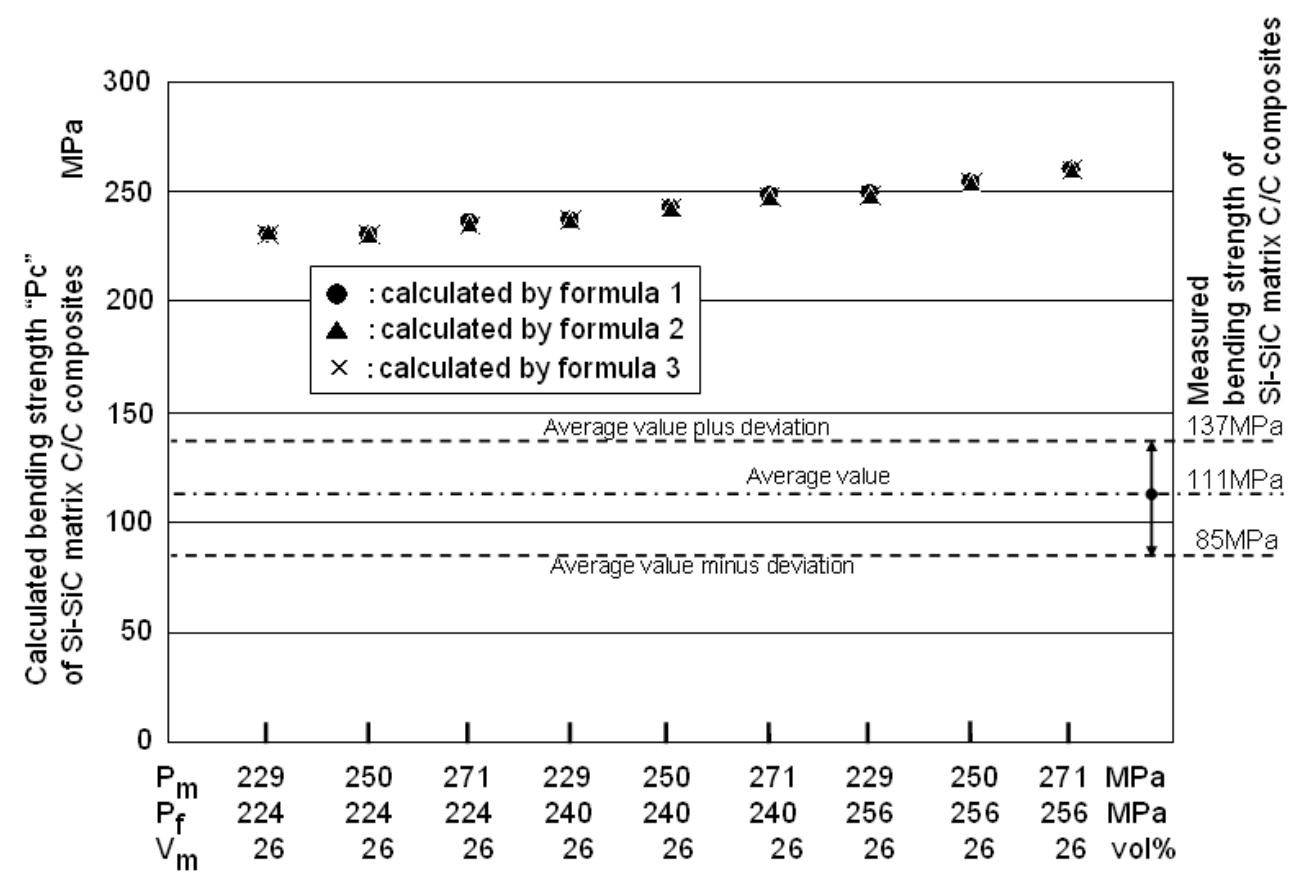

Figure 9. Bending strength $P_{c}$ of $\mathrm{Si}-\mathrm{SiC}$ matrix $\mathrm{C} / \mathrm{C}$ composite

Herein, $P_{f}=$ Characteristic values $(240 \pm 16 \mathrm{MPa})$ of base material $\mathrm{C} / \mathrm{C}$ composite

$P_{m}=$ Characteristic values $(250 \pm 21 \mathrm{MPa})$ of $\mathrm{Si}-\mathrm{SiC}$ matrix $V_{f}=$ Volume ratio (26 Vol.\%) of Si-SiC matrix

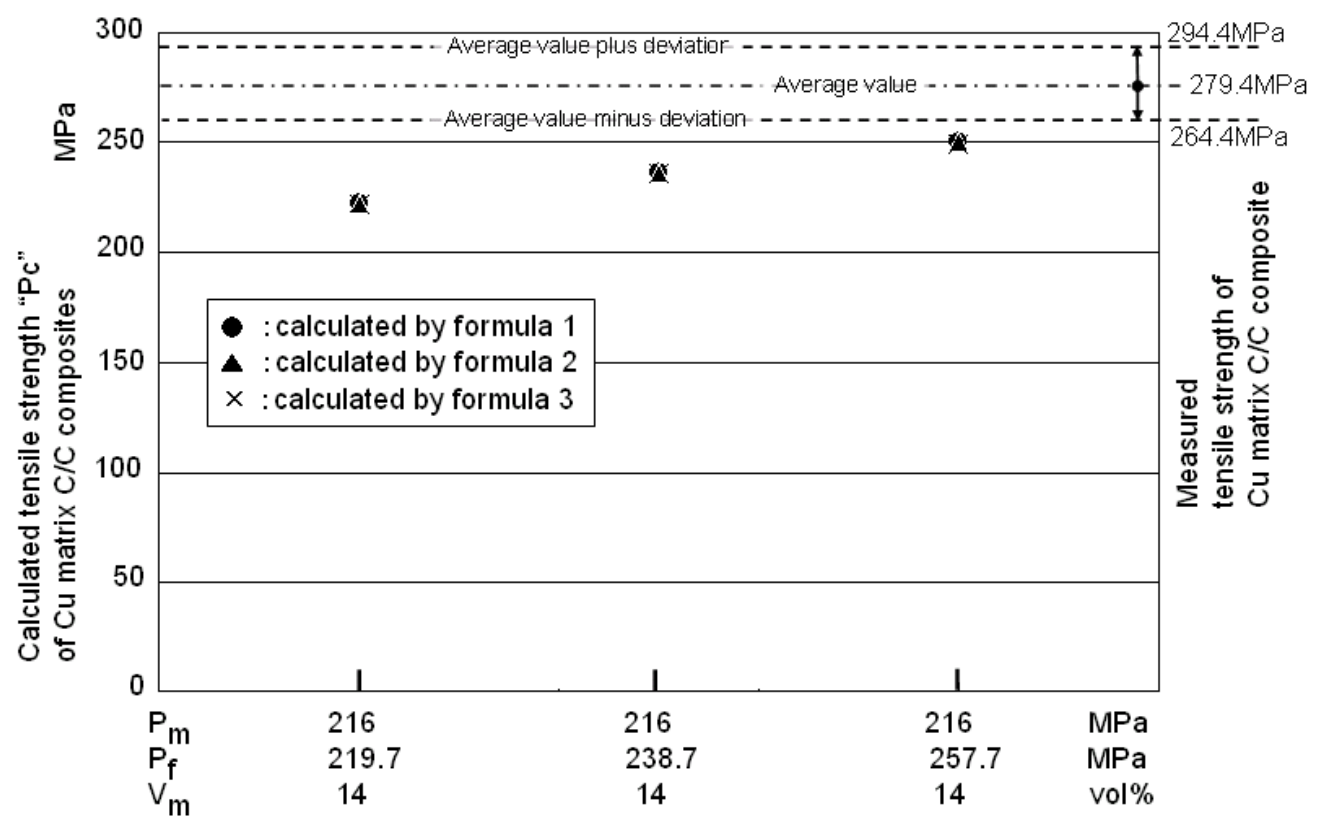

Figure 10. Tensile strength $P_{c}$ of $\mathrm{Cu}$ matrix $\mathrm{C} / \mathrm{C}$ composite

Herein, $P_{f}=$ Characteristic values $(238.7 \pm 19 \mathrm{MPa})$ of base material $\mathrm{C} / \mathrm{C}$ composite $P_{m}=$ Characteristic values $(216 \mathrm{MPa})$ of $\mathrm{Cu}$ matrix $V_{f}=$ Volume ratio (14 Vol.\%) of Cu matrix 


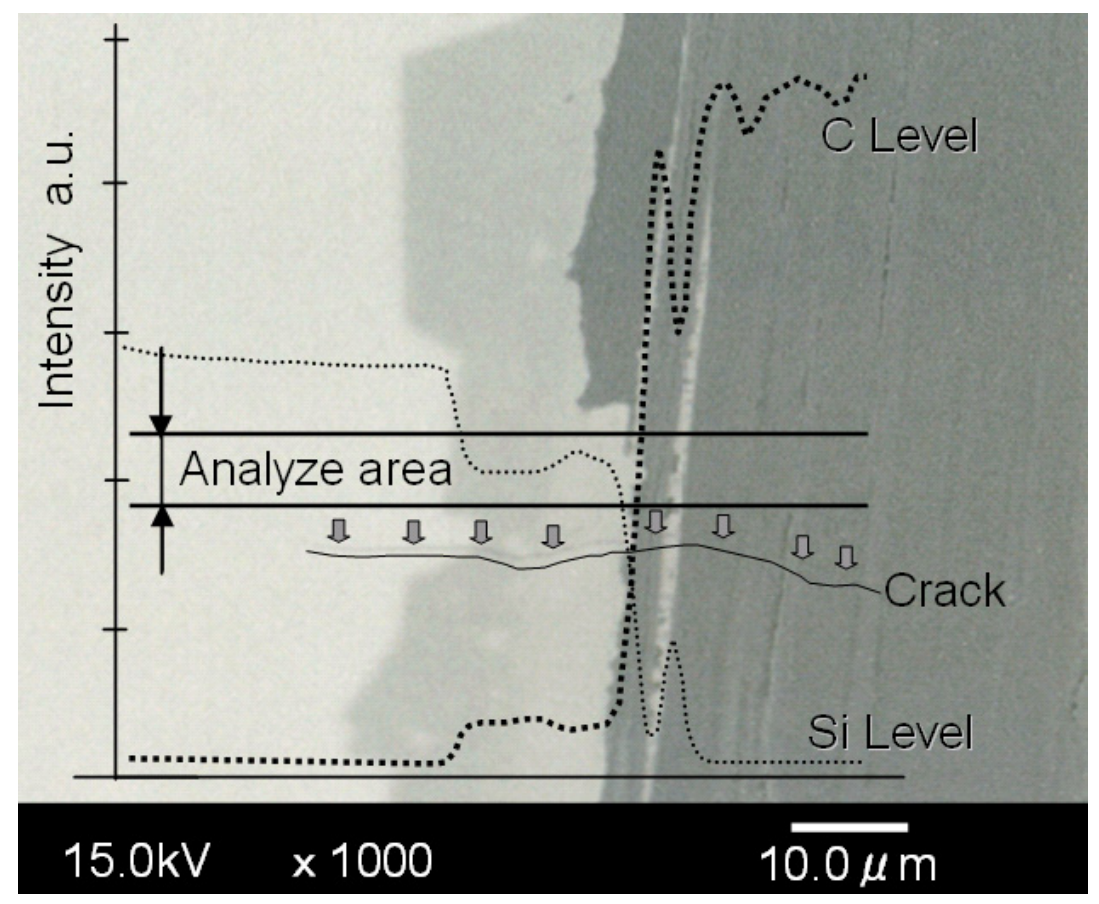

Figure 11. Microstructure (SEM) of $\mathrm{Si}-\mathrm{SiC}$ matrix $\mathrm{C} / \mathrm{C}$ composite and gradient of concentration of $\mathrm{Si}$ and $\mathrm{C}$

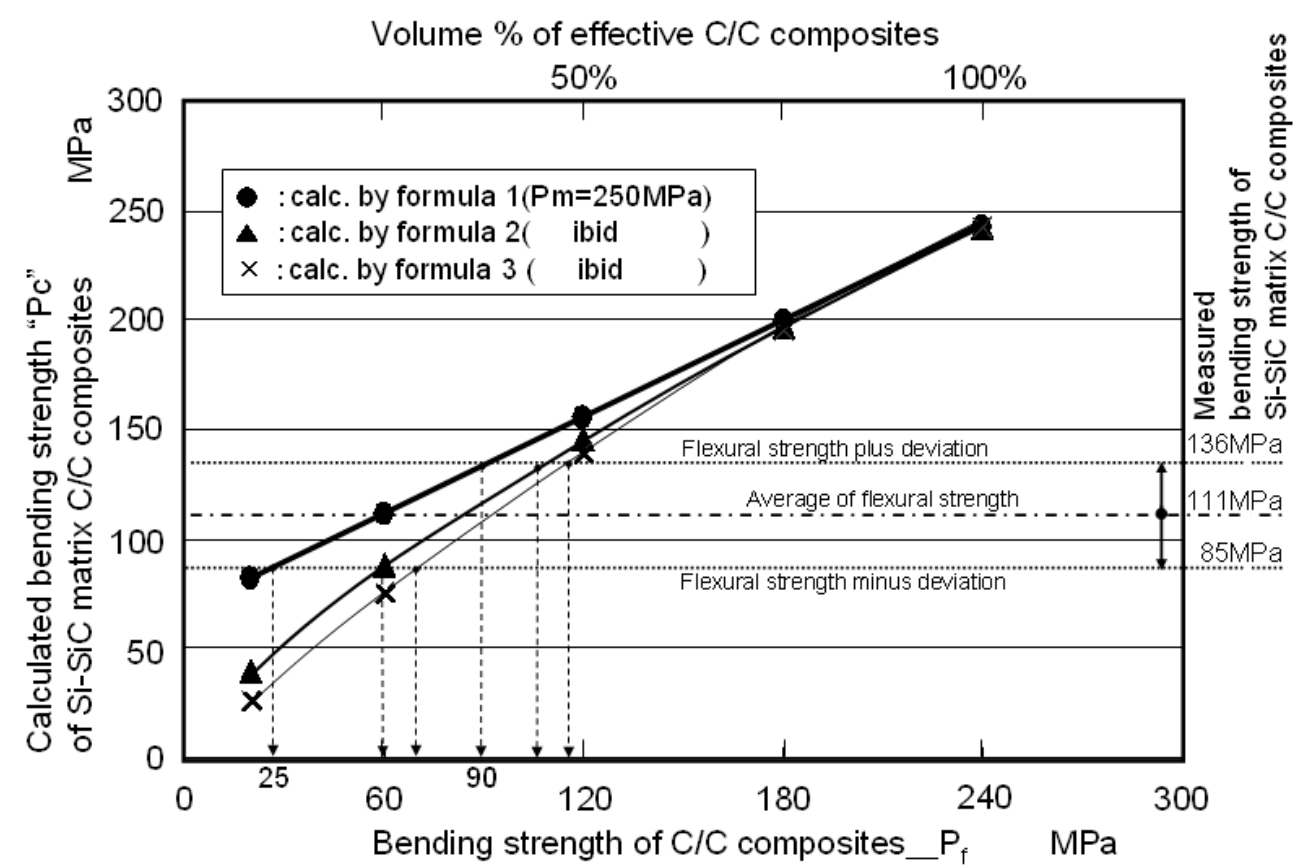

Figure 12. Estimated amount of damage of carbon fiber yarn using complex rules 

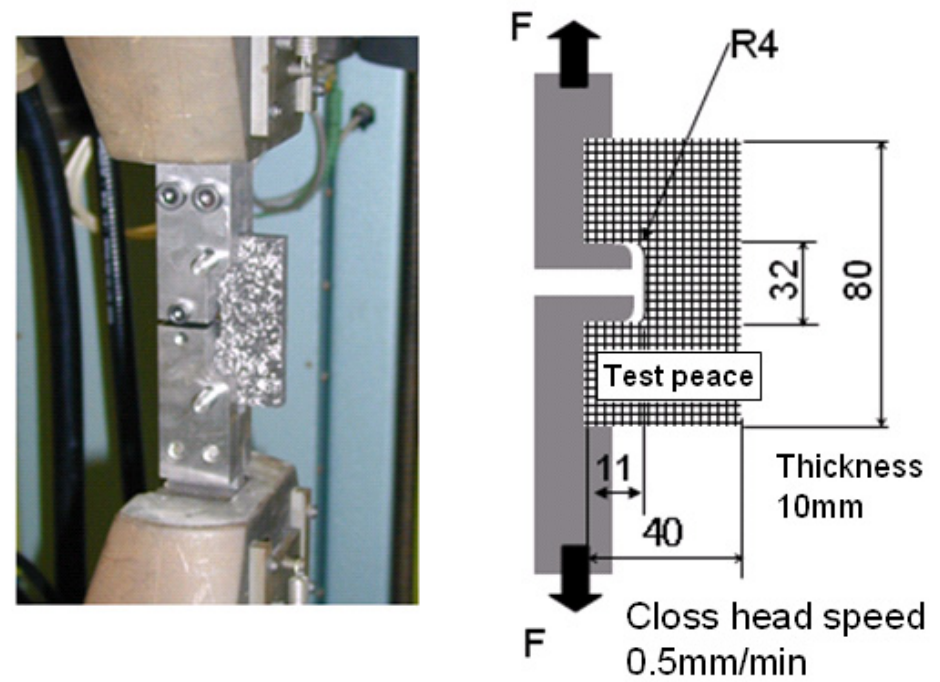

Figure 13. Evaluation experimental method of breaking load using notched specimens

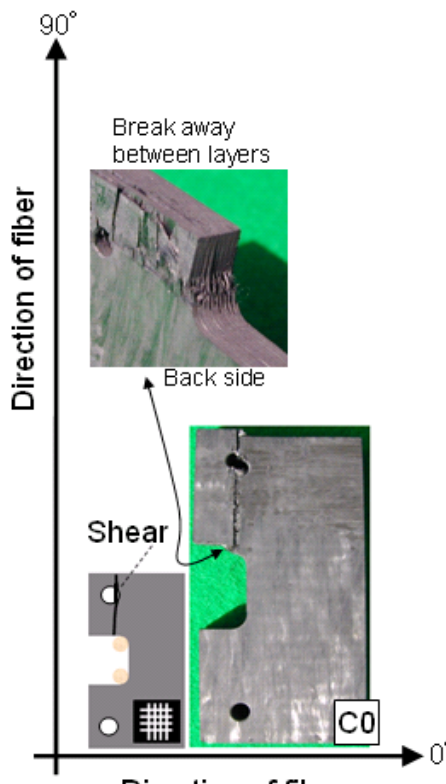

Direction of fiber

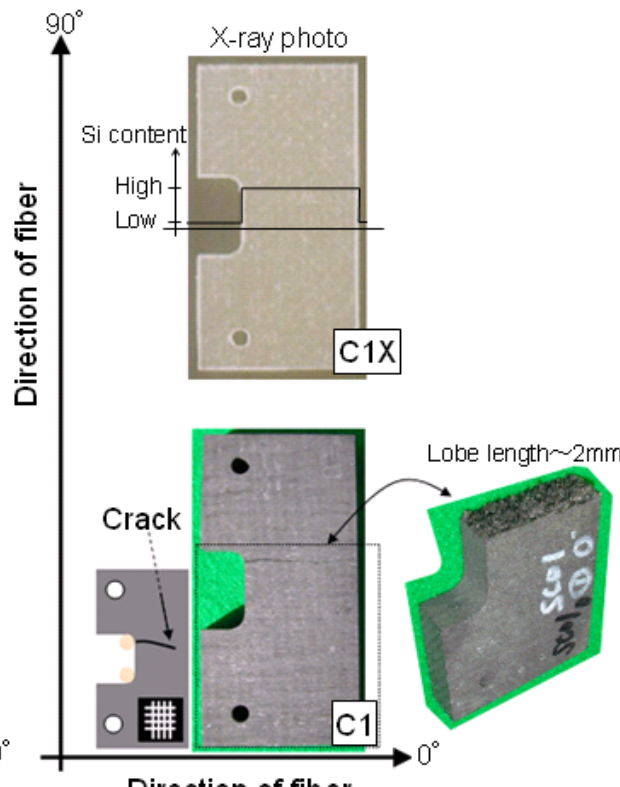

Direction of fiber

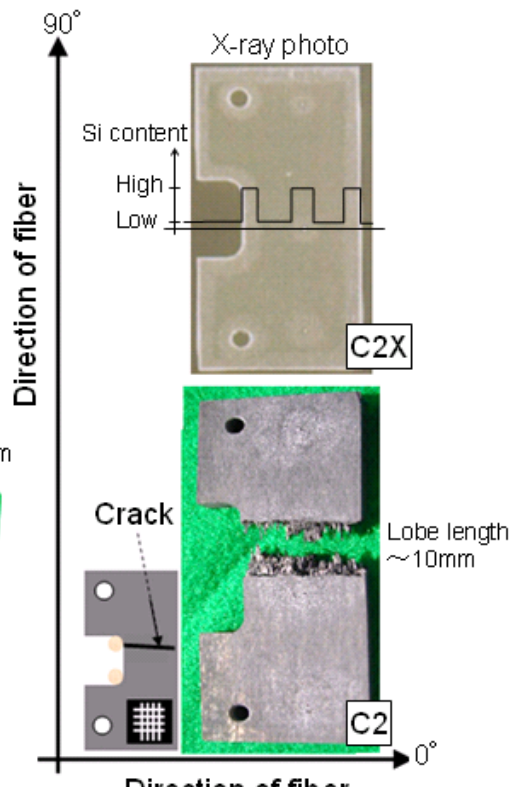

Direction of fiber

Figure 14. Result of evaluation of breaking load using notched specimens

State after breakage: $\mathrm{C} / \mathrm{C}$ composite for $\mathrm{C} 0, \mathrm{Si}-\mathrm{SiC}$ matrix $\mathrm{C} / \mathrm{C}$ composite for $\mathrm{C} 1$, partial $\mathrm{Si}-\mathrm{SiC}$ matrix $\mathrm{C} / \mathrm{C}$ composite for $\mathrm{C} 2$

$\mathrm{X}$-ray photo: $\mathrm{Si}-\mathrm{SiC}$ matrix $\mathrm{C} / \mathrm{C}$ composite for $\mathrm{C} 1 \mathrm{X}$, partial $\mathrm{Si}-\mathrm{SiC}$ matrix $\mathrm{C} / \mathrm{C}$ composite for $\mathrm{C} 2 \mathrm{X}$ 